УДК 338.45

DOI: 10.18101/2304-4446-2019-4-11-21

\title{
ОБ ЭФФЕКТИВНОСТИ СТРОИТЕЛЬСТВА ТЭЦ-2 В Г. УЛАН-УДЭ
}

\section{(C) Борисов Геннадий Очирович}

кандидат экономических наук, старший научный сотрудник

E-mail: borisovgo@bk.ru

\section{(C) Здаров Роман Андреевич}

младший научный сотрудник

E-mail: zdarovroman@mail.ru

Бурятский научный центр СО РАН

Россия 670047, г. Улан-Удэ, ул. Сахьяновой, 8

Авторы анализируют состояние теплоэнергоснабжения города Улан-Удэ. Рассчитаны и приведены балансы производства и потребления тепловой энергии, фактические и перспективные балансы тепловой мощности и тепловой нагрузки ТЭЦ-1 и ТЭЦ-2. Приведены данные о фактической себестоимости производства и передачи тепловой энергии в г. Улан-Удэ за 2017 год. Произведены расчеты экономических потерь и выявлены причины удорожания тарифов на тепло и электроэнергию, вызванные отставанием завершения строительства У-УТЭЦ-2. В статье проведен анализ экологического состояния г. Улан-Удэ по уровню загрязнения атмосферного воздуха. Выявлено, что город в течение десяти лет включается в «Приоритетный» список городов с очень высоким уровнем загрязнения атмосферного воздуха. Значительную долю загрязнений вносят котельные, ТЭЦ-1, ТЭЦ-2 и печные установки индивидуальной жилой застройки. Показано, что ввод ТЭЦ-2 позволит значительно снизить загрязнение города. Для решения вопроса о завершении строительства Улан-Удэнской ТЭЦ-2 необходимо решение правительства РФ и включение проекта в Национальную программу развития Дальнего Востока до 2025 г. и на перспективу до 2035 г.

Ключевые слова: город Улан-Удэ; ТЭЦ-2; котельная; бензапирен; теплоэнергоснабжение; коммунальное хозяйство; электроэнергетика.

\section{Для цитирования}

Борисов Г. О., Здаров Р. А. Об эффективности строительства ТЭЦ-2 в г. Улан-Удэ // Вестник Бурятского государственного университета. Экономика и менеджмент. 2019. № 4. С. 11-21.

В настоящее время централизованное теплоснабжение жилищнокоммунального сектора, предприятий и организаций г. Улан-Удэ осуществляется от двух ТЭЦ (Улан-Удэнской ТЭЦ-1 и ТЭЦ-2 «Генерация Бурятии», филиал ПАО «ТГК-14»), 36 муниципальных котельных, переданных в эксплуатацию Улан-Удэнскому энергетическому комплексу, филиалу ПАО «ТГК-14», и 98 ведомственных котельных (учтены в Схеме теплоснабжения), работающих на угле, мазуте, дизельном топливе, древесных опилках и электроэнергии. Суммарная установленная электрическая мощность энергоисточников города составляет 148,77 МВт, тепловая без учета децентрализованных систем теплоснабжения около 2250 Гкал/ч, в том числе по энергоисточникам комбинированной выработки тепловой и электрической энергии - 688 Гкал/ч $(31 \%$ от суммарной тепловой 
мощности энергоисточников города). Улан-Удэнская ТЭЦ-1 имеет в своем распоряжении четыре турбины: Р-8,4-3,4/1,0, Р-12-34/1, ПТ-30-90/13/2,5 и Тп-100/110-8,8, мощность последней турбины снижена до 98,37 МВт. Давление пара турбин Улан-Удэнской ТЭЦ-1 составляет 34 ата и 90 ата. Возраст турбин составляет 21, 14, 54 и 7 лет соответственно.

На Улан-Удэнской ТЭЦ-2 установлены четыре котла пускопиковой котельной мощностью 380 Гкал в час. Подготовлена инженерная инфраструктура для обеспечения работы двух теплофикационных энергоблоков Т-180/210.

В таблицах 1 и 2 представлены балансы производства и потребления тепловой энергии в городе. Балансы составлены по данным «Схем и программ развития электроэнергетики» Республики Бурятия за соответствующие годы и годовых отчетов ТГК-14.

Таблица 1

Баланс производства и потребления тепловой энергии

\begin{tabular}{|c|c|c|c|}
\hline Наименование источника тепла & $\begin{array}{c}\text { Ед. } \\
\text { измерения }\end{array}$ & 2015 r. & 2016 r. \\
\hline \multicolumn{4}{|l|}{ У-УТЭЦ-1 } \\
\hline Собственные нужды & Гкал & 97121 & 93435 \\
\hline $\begin{array}{l}\text { Отпуск тепла внешним потребителям с коллекто- } \\
\text { ров ТЭЦ }\end{array}$ & Гкал & 1641162 & 1677147 \\
\hline $\begin{array}{l}\text { Удельный расход условного топлива на отпущен- } \\
\text { ную тепловую энергию }\end{array}$ & кг/Гкал & 150,3 & 154,56 \\
\hline $\begin{array}{l}\text { Расход условного топлива на отпущенную тепло- } \\
\text { вую энергию, т у.т. }\end{array}$ & т у.т. & 246696 & 259214 \\
\hline $\begin{array}{l}\text { Полезный отпуск тепла потребителям, в том чис- } \\
\text { ле: }\end{array}$ & Гкал & - & 1434523 \\
\hline горячая вода & Гкал & - & 12728994 \\
\hline горячая вода ЛВРЗ & Гкал & - & 67059 \\
\hline пар ЛВРЗ & Гкал & - & 94565 \\
\hline Присоединеная тепловая нагрузка & Гкал/ч & 530,46 & 584,13 \\
\hline У-УТЭЦ-2 & & & 1434523 \\
\hline Собственные нужды & Гкал & 33220 & 31658 \\
\hline $\begin{array}{l}\text { Отпуск тепла внешним потребителям с коллекто- } \\
\text { ров ТЭц }\end{array}$ & Гкал & 791240 & 686361 \\
\hline $\begin{array}{l}\text { Удельный расход условного топлива на отпущен- } \\
\text { ную тепловую энергию }\end{array}$ & кг/Гкал & 173,59 & 172,94 \\
\hline $\begin{array}{l}\text { Расход условного топлива на отпущенную тепло- } \\
\text { вую энергию }\end{array}$ & т у.т. & 137355 & 118702 \\
\hline Полезный отпуск тепла потребителям & Гкал & - & 5764795 \\
\hline горячая вода & Гкал & - & 576479 \\
\hline пар & Гкал & - & 0 \\
\hline Присоединеная тепловая нагрузка & Гкал/ч & 343,27 & 333,14 \\
\hline \multicolumn{4}{|l|}{ Котельные } \\
\hline Отпуск тепла внешним потребителям & Гкал & 1117154 & 978982,8 \\
\hline $\begin{array}{l}\text { Расход условного топлива на отпущенную тепло- } \\
\text { вую энергию }\end{array}$ & т у.т. & 253247,6 & 206800,5 \\
\hline Присоединеная тепловая нагрузка & Гкал/ч & 381,9 & 381,9 \\
\hline \multicolumn{4}{|l|}{ в том числе по котельным У-УЭК } \\
\hline Выработка тепла & Гкал & 459891 & 449831 \\
\hline Собственные нужды & Гкал & 22447 & 21867 \\
\hline
\end{tabular}


Баланс тепловой мощности и тепловой нагрузки при существующем составе оборудования У-УТЭЦ-1 и У-УТЭЦ-2

\begin{tabular}{|c|c|c|c|c|c|}
\hline Наименование & 2016 & 2019 & 2020 & 2025 & 2030 \\
\hline \multicolumn{6}{|l|}{ Улан-Удэнская ТЭЦ-1 } \\
\hline Установленная тепловая мощность, Гкал/ч & 688,0 & 688,0 & 688,0 & 688,0 & 688,0 \\
\hline Располагаемая тепловая мощность, Гкал/ч & 488,0 & 488,0 & 488,0 & 488,0 & 488,0 \\
\hline Собственные нужды, Гкал/ч & 26,5 & 26,5 & 26,5 & 26,5 & 26,5 \\
\hline $\begin{array}{l}\text { Тепловая нагрузка на коллекторах по дого- } \\
\text { ворам, Гкал/4 }\end{array}$ & 680,4 & 731,3 & 731,3 & 731,4 & 735,3 \\
\hline Тепловые потери в сетях, Гкал/ч & 84,7 & 91,1 & 91,1 & 91,1 & 91,6 \\
\hline $\begin{array}{l}\text { Тепловая нагрузка потребителей } \\
\text { (водяные теплосети), Гкал/ч, в т. ч: }\end{array}$ & 584,1 & 628,5 & 628,5 & 628,5 & 632,0 \\
\hline отопление и вентиляция, Гкал/ч & 517,0 & 551,4 & 551,4 & 551,4 & 554,9 \\
\hline нагрузка ГВС, Гкал/ч & 67,1 & 77,1 & 77,1 & 77,1 & 77,1 \\
\hline Пар, Гкал/ч & 11,6 & 11,6 & 11,6 & 11,7 & 11,7 \\
\hline $\begin{array}{l}\text { Расчетная тепловая нагрузка на коллекто- } \\
p a x, \text { Гкал/4 }\end{array}$ & 509,0 & 550,7 & 550,7 & 550,8 & 554,0 \\
\hline $\begin{array}{l}\text { Дефицит(-)/ } \\
\text { Резерв (+) по договорной нагрузке, Гкал/ч }\end{array}$ & $-218,9$ & $-269,7$ & $-269,7$ & $-269,8$ & $-273,8$ \\
\hline $\begin{array}{l}\text { Дефицит(-)/ } \\
\text { Резерв (+) по договорной нагрузке, \% }\end{array}$ & $-44,9$ & $-55,3$ & $-55,3$ & $-55,3$ & $-56,1$ \\
\hline $\begin{array}{l}\text { Дефицит(-)/ } \\
\text { Резерв (+) по расчетной нагрузке, Гкал/ч }\end{array}$ & $-59,0$ & $-100,7$ & $-100,7$ & $-100,9$ & $-104,2$ \\
\hline $\begin{array}{l}\text { Дефицит(-)/ } \\
\text { Резерв (+) по расчетной нагрузке, \% }\end{array}$ & $-12,1$ & $-20,6$ & $-20,6$ & $-20,7$ & $-21,3$ \\
\hline \multicolumn{6}{|c|}{ Улан-Удэнская ТЭЦ-2 } \\
\hline Установленная тепловая мощность, Гкал/ч & 380,0 & 380,0 & 380,0 & 380,0 & 380,0 \\
\hline Располагаемая тепловая мощность, Гкал/ч & 235,0 & 235,0 & 235,0 & 235,0 & 235,0 \\
\hline Собственные нужды, Гкал/ч & 4,7 & 4,7 & 4,7 & 4,7 & 4,7 \\
\hline $\begin{array}{l}\text { Тепловая нагрузка на коллекторах по дого- } \\
\text { ворам, Гкал/4 }\end{array}$ & 386,4 & 459,5 & 469,9 & 491,1 & 506,5 \\
\hline Тепловые потери в сетях, Гкал/ч & 53,3 & 63,4 & 64,8 & 67,7 & 69,9 \\
\hline $\begin{array}{l}\text { Тепловая нагрузка потребителей } \\
\text { (водяные теплосети), Гкал/ч, в т. ч: }\end{array}$ & 333,1 & 396,1 & 405,1 & 423,3 & 436,6 \\
\hline отопление и вентиляция, Гкал/ч & 299,8 & 338,3 & 344,2 & 355,9 & 367,6 \\
\hline нагрузка ГВС, Гкал/ч & 33,3 & 57,8 & 60,9 & 67,4 & 69,0 \\
\hline Пар, Гкал/4 & 0,0 & 0,0 & 0,0 & 0,0 & 0,0 \\
\hline $\begin{array}{l}\text { Расчетная тепловая нагрузка на коллек- } \\
\text { торах, Гкал/4 }\end{array}$ & 187,9 & 223,4 & 228,5 & 238,8 & 246,2 \\
\hline $\begin{array}{l}\text { Дефицит(-)/Резерв (+) по договорной нагруз- } \\
\text { ке, Гкал/ч }\end{array}$ & $-156,1$ & $-229,2$ & $-239,6$ & $-260,8$ & $-276,2$ \\
\hline $\begin{array}{l}\text { Дефицит(-)/ } \\
\text { Резерв (+) по договорной нагрузке, \% }\end{array}$ & $-66,4$ & $-97,5$ & $-102,0$ & $-111,0$ & $-117,5$ \\
\hline $\begin{array}{l}\text { Дефицит(-)/ } \\
\text { Резерв (+) по расчетной нагрузке, Гкал/ч }\end{array}$ & 42,4 & 6,9 & 1,8 & $-8,5$ & $-15,9$ \\
\hline $\begin{array}{l}\text { Дефицит(-)/ } \\
\text { Резерв (+) по расчетной нагрузке , \% }\end{array}$ & 18,0 & 2,9 & 0,8 & $-3,6$ & $-6,8$ \\
\hline
\end{tabular}


Представленные в таблице 2 балансы показывают, что существующий состав оборудования У-УТЭЦ-1 и У-УТЭЦ-2 не способен обеспечить перспективную тепловую нагрузку. По У-УТЭЦ-1 имеется дефицит тепловой мощности уже на существующей нагрузке, по У-УТЭЦ-2 дефицит мощности появится в 2019 г. Таким образом, для обеспечения перспективных нагрузок необходим ввод дополнительных тепловых мощностей.

В таблице 3 приведены данные о фактической себестоимости производства и передачи тепловой энергии на различных источниках тепла в г. Улан-Удэ, из которой видно, что тепло от котельных значительно дороже тепловой энергии, отпускаемой от ТЭЦ-1с использованием когенерации.

Таблица 3

Справка о фактической себестоимости производства и передачи тепловой энергии в г. Улан-Удэ за 2017 г.

(данные Республиканской службы тарифов)

\begin{tabular}{|c|c|c|c|c|c|c|c|}
\hline \multirow{2}{*}{ 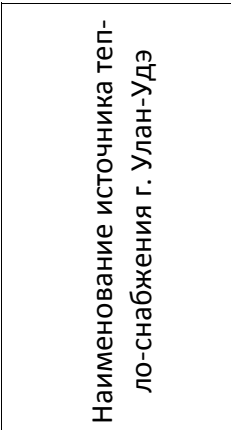 } & \multirow{2}{*}{ 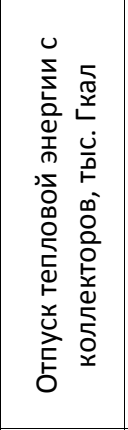 } & \multirow{2}{*}{ 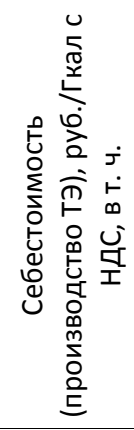 } & \multirow{2}{*}{ 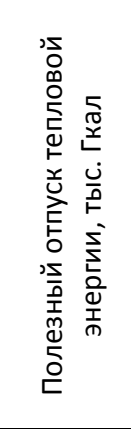 } & \multirow{2}{*}{ 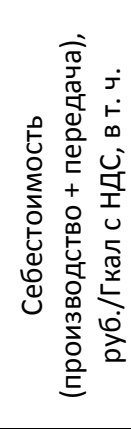 } & \multirow{2}{*}{ 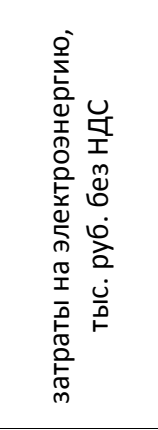 } & \multicolumn{2}{|c|}{$\begin{array}{c}\text { затраты на приобретение } \\
\text { топлива, тыс. руб. без } \\
\text { НДС }\end{array}$} \\
\hline & & & & & & 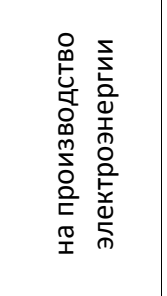 & 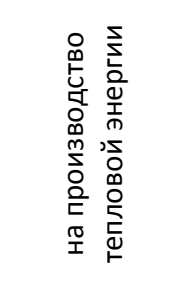 \\
\hline 1 М-1 & 1509,76 & 886,53 & 1235,09 & 1436,77 & 14011,65 & 42 & \\
\hline ТЭЦ-2 & 2617 & 1089,60 & & 1680,11 & 0111601 & & \\
\hline $\begin{array}{l}\text { Муниципальные } \\
\text { котельные }\end{array}$ & 441,80 & 2221,56 & 344,77 & 3378,15 & 261176,80 & & 282187,81 \\
\hline $\begin{array}{l}\text { Ведомственные } \\
\text { котельные }\end{array}$ & 168,74 & 1569,17 & 147,28 & 2072,94 & 31415,81 & & 1083 \\
\hline Итого & 2756,79 & 1189,15 & 2283,08 & 1847,07 & 390720,86 & 425024,66 & 1222486,71 \\
\hline
\end{tabular}

В таблице 4 представлены данные по технико-экономическим показателям Красноярской ТЭЦ-3, на которой установлен теплофикационный энергоблок 200 МВт, аналогичный запроектированным на Улан-Удэнской ТЭЦ-2, а также удельные расходы на выработку электроэнергии Гусиноозерской ГРЭС, работающей в конденсационном режиме. С использованием данных таблиц 3 и 4 проведены расчеты ежегодных экономических потерь из-за неиспользования возможной выработки электроэнергии на тепловом потреблении (когенерации) в г. УланУдэ по причине отставания ввода теплофикационных энергоблоков на ТЭЦ-2. 
Технико-экономические показатели Красноярской ТЭЦ-3 и Гусиноозерской ГРЭС

\begin{tabular}{|c|c|c|c|}
\hline \multicolumn{3}{|c|}{ Основные ТЭП Красноярской ТЭЦ-3, факт за 2018 г. (БЛОК) } & \multirow{2}{*}{\begin{tabular}{|c|} 
ТЭП ГО ГРЭС, \\
2018 г. \\
\end{tabular}} \\
\hline Выработка ЭЭ & тыс. кВт.4 & 862654,519 & \\
\hline Расход ЭЭ на СН & тыс. кВт.4 & 63335,013 & \\
\hline Отпуск ЭЭ с шин & тыс. кВт·ч & 799319,506 & \\
\hline Отпуск ТЭ & тыс. Гкал & 858,374 & \\
\hline \multicolumn{4}{|l|}{ Расход топлива: } \\
\hline В т. ч. уголь & Tыс. THт & 609,747 & \\
\hline мазут & TbIc. THт & 0,287 & \\
\hline УРУТ на ЭЭ & $\mathrm{r} / \mathrm{KBT} \cdot \mathrm{4}$ & 234,7 & 364,37 \\
\hline УРУТ на ТЭ & кг/Гкал & 183,0 & \\
\hline УРУТ на ЭЭ по Т-циклу & $\mathrm{r} / \mathrm{KBT} \cdot 4$ & 150,9 & \\
\hline УРУТ на ЭЭ по К-циклу & $\mathrm{r} / \mathrm{KBT} \cdot 4$ & 391,3 & \\
\hline Стоимость мощности & руб/МBт·ч & 453,08 & \\
\hline Стоимость Гкал & руб/Гкал & 1212 & \\
\hline Расход условного топлива на э/э & тыс. т у.т. & 187,6 & 291,2 \\
\hline \multirow{2}{*}{$\begin{array}{l}\text { Перерасход топлива при конденсационной вы- } \\
\text { работке э/э }\end{array}$} & тыс. т у.т. & & 103,6 \\
\hline & Tыс. THт & & 145 \\
\hline Стоимость 1 тнт & руб. & & 1622,44 \\
\hline Стоимость, всего & млн руб. & & 235,3 \\
\hline
\end{tabular}

Произведен расчет перерасхода топлива (табл. 4), который равен 145 тыс. тонн стоимостью 235,3 млн руб. Снижение расходов на выработку тепла при закрытии муниципальных котельных равно 388 млн руб. [(3378,15-1436,77) * $200=388$ млн руб. (табл. 3)], при закрытии ведомственных котельных - 32 млн руб. [(2072,94-1436,77) * 50= 32 млн руб.]. Снижение выработки муниципальных котельных составило 200 тыс. Гкал, ведомственных - 50 тыс. Гкал. Итого: 420 млн руб. Снижение затрат на электроэнергию: 84 116,61 - (14011,65 : 1 $509,761) * 636,479=78,2$ млн руб.

Снижение затрат на амортизацию и обслуживание: ремонтный фонд ТЭЦ-2 составил в 2017 г. 50 млн руб., фонд оплаты труда - 113 млн руб., как минимум $30 \%$ этих расходов идет на обслуживание объектов инфраструктуры, введенной в строй для работы двух энергоблоков, то есть дополнительная нагрузка на стоимость тепла составляет 50 млн руб.

Таким образом, ежегодно по этим показателям потребитель переплачивает 1018,8 млн руб. При гарантированном источнике тепла появится возможность осуществления бизнес-проектов по закрытию или переводу котельных в пиковый режим, подключению коттеджных поселков и индивидуального жилья в зоне действия ТЭЦ-1 и ТЭЦ-2, которые значительно увеличат эффективность системы теплоснабжения города. Потери в сети 220 кВт при передаче из ГО ГРЭС составят не менее 24 млн кВт.ч $(2 \%, 6$ тыс. часов использования максимума, мощность 200 МВт). При себестоимости одного кВт·ч на ТЭЦ-1 1,89 руб. стоимость потерь составит 45 млн руб. 
В г. Улан-Удэ на протяжении ряда лет отмечается наиболее напряженная ситуация по уровню загрязнения атмосферного воздуха, который согласно данным Бурятского центра по гидрометеорологии и мониторингу окружающей среды на протяжении более 10 лет включается в «Приоритетный» список городов с очень высоким уровнем загрязнения атмосферного воздуха.

В г. Улан-Удэ отмечалось превышение предельно допустимых концентраций (ПДКсс) бензапирена в 10,2 раза, взвешенных веществ в 1,9 раза, формальдегида в 1,3 раза, мелкодисперсных взвешенных частиц РМ10 и РМ 2,5 в 1,1 и 1,4 раза соответственно. Относительно 2016 г. наблюдалось увеличение среднегодовых концентраций взвешенных веществ, углерода оксида, серы диоксида, азота оксида, формальдегида и бензапирена (табл. 5).

Таблица 5

Динамика среднегодовых концентраций загрязняющих веществ

\begin{tabular}{|l|c|c|c|c|}
\hline \multicolumn{1}{|c|}{ Показатель } & $\mathbf{2 0 1 6}$ & $\mathbf{2 0 1 7}$ & $\mathbf{2 0 1 8}$ & $\begin{array}{c}\text { Tемп прироста в 2018 г. } \\
\text { относительно 2016 г., \% }\end{array}$ \\
\hline Азота диоксид & 1 & 0,93 & 1 & 0 \\
\hline Взвешенные вещества & 1,77 & 1,75 & 1,88 & 6,21 \\
\hline Углерода оксид & 0,13 & 0,17 & 0,17 & 30,77 \\
\hline Серы диоксид & 0,2 & 0,26 & 0,36 & 80 \\
\hline Формальдегид & 1,1 & 1 & 1,3 & 18,18 \\
\hline Фенол & 1 & 1 & 1 & 0 \\
\hline Бенз(а)пирен & 6,8 & 7,6 & 10,2 & 50 \\
\hline Азота оксид & 0,23 & 0,32 & 0,42 & 82,61 \\
\hline Озон & 1,23 & 0,9 & 1,07 & $-13,01$ \\
\hline Аммиак & 0,35 & 0,2 & 0,1 & $-71,43$ \\
\hline Углерод (сажа) & 0,86 & 0,28 & 0,34 & $-60,47$ \\
\hline Сероводород (в мг/м ${ }^{*}$ & 0,001 & 0,001 & 0,002 & 100 \\
\hline Взвешенные частицы РМ10 & - & 1,2 & 1,13 & \\
\hline Взвешенные частицы РМ2,5 & - & 1,34 & 1,37 & \\
\hline
\end{tabular}

По данным Бурятского центра по гидрометеорологии и мониторингу окружающей среды, наибольшее превышение ПДК бензапирена, диоксида азота в г. Улан-Удэ наблюдается в отопительный период с сентября по май. Например, в январе 2018 г. среднемесячная концентрация бензапирена составляла 34 ПДК, а диоксида азота - 1,4 ПДК. В летние месяцы эти показатели были в норме. Исследования, проведенные в 1998 г. НИИ охраны атмосферного воздуха г. СанктПетербурга, показали, что количество выбросов бензапирена зависит от температуры сжигания топлива в топке. Наиболее высокие концентрации бензапирена наблюдаются в котлах мелких котельных и в печах, сжигающих уголь и дрова. В котельных ТЭЦ выход бензапирена в разы ниже.

Город Улан-Удэ по ряду экологических показателей входит в число экологически неблагополучных городов Российской Федерации. В первую очередь это связано со сжиганием угля на электростанции и котельных, расположенных на

1 О состоянии санитарно-эпидемиологического благополучия населения в городе УланУдэ в 2018 году: доклад главного государственного санитарного врача по Республике Бурятия С. С. Ханхареева. 
территории Улан-Удэ, также на экологическую обстановку влияет золоотвал, расположенный в центре города.

В центре города находятся Улан-Удэнская ТЭЦ-1, большое количество средних и небольших котельных, а также золоотвал. В соответствии со схемой теплоснабжения с целью улучшения экологической обстановки планируется закрытие в г. Улан-Удэ 52 котельных и перевод трех котельных в холодный резерв. Планируется передача тепловой нагрузки на ТЭЦ-2.

Более высокая эффективность золоуловителей на ТЭЦ-2 позволит снизить объем выбросов вредных веществ в атмосферу. Дополнительным фактором улучшения экологической ситуации в г. Улан-Удэ при переносе производства тепловой энергии из центра города на ТЭЦ-2 является преобладающие направления ветра в месте нахождения ТЭЦ-2 (рис. 1, 2).

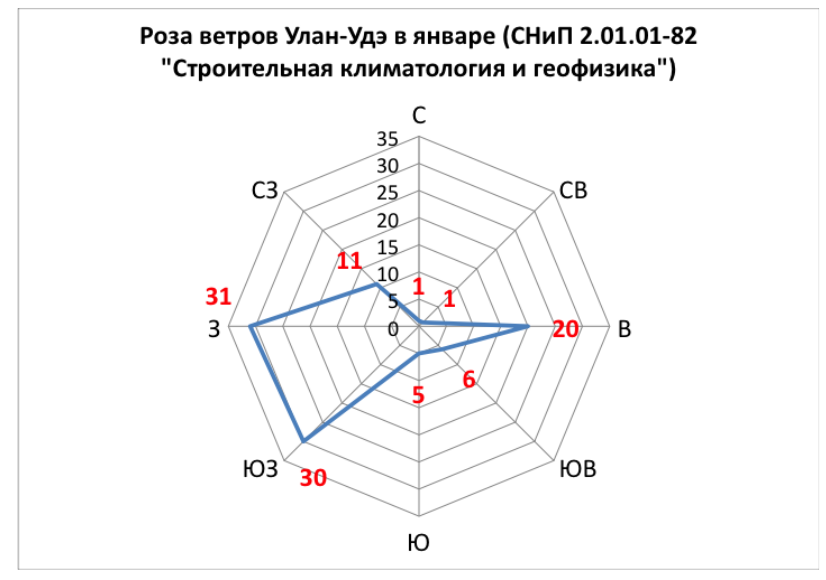

Рис. 1. Сведения о розе ветров в городе Улан-Удэ на январь

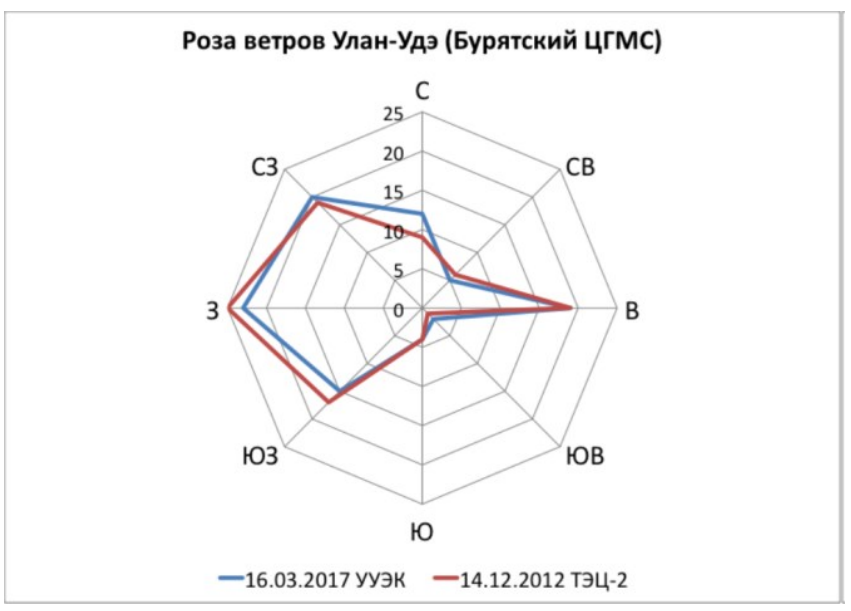

Рис. 2. Среднегодовые данные о розе ветров в г. Улан-Удэ на основе данных Бурятского ЦГМС за 2012 и 2017 гг. 
В соответствии с данными Бурятского ЦГМС о розе ветров в г. Улан-Удэ в месте расположения Улан-Удэнской ТЭЦ-2 выбросы вредных веществ вместе с ветром будут перемещаться в направлении от города $75 \%$ времени.

Таким образом, ввод в эксплуатацию энергоблоков Улан-Удэнской ТЭЦ-2 с КПД золоуловителей $99 \%$ и передача нагрузки теплоснабжения от котельных снизят выбросы в 2-4 раза (КПД золоуловителей на котельных $-60-83 \%$; КПД золоуловителей на пиковой водогрейной станции ТЭЦ-2 - 87-89\%). С учетом розы ветров объем выбросов снизится в 8-16 раз, в районе У-УТЭЦ-2 передача теплоснабжения от котельных, расположенных в черте города, с их последующим закрытием, а также от ТЭЦ-1 приведет к снижению выбросов в Улан-Удэ на $75 \%$. Передача нагрузки с ТЭЦ-1 на ТЭЦ-2 приведет к снижению выбросов от ТЭЦ-1 в 1,5 раза, а также снизит количество золошлаковых отходов, сбрасываемых на золоотвал, расположенный в центре Улан-Удэ.

Кроме того, увеличение тепловой мощности ТЭЦ-2 и снижение стоимости тепла позволят перевести на централизованное теплоснабжение индивидуальную жилищную застройку (коттеджные поселки) в южной и юго-восточной части города. Все это, а также целенаправленная работа по снижению вредных выбросов коммунальных и производственных котельных позволят значительно улучшить экологическую обстановку в г. Улан-Удэ и в целом на Байкальской природной территории.

Улан-Удэ - единственный несбалансированный с точки зрения электроэнергетики город с населением более 100 тысяч человек в Сибири и на Дальнем Востоке. При мощности потребления более 350 МВт установленная мощность ТЭЦ-1 составляет 150 МВт. На рис. 3 представлены данные по численности городов и установленной мощности ТЭЦ. В анализе не учитывались генерирующие мощности ГЭС и ГРЭС, расположенных в городах.

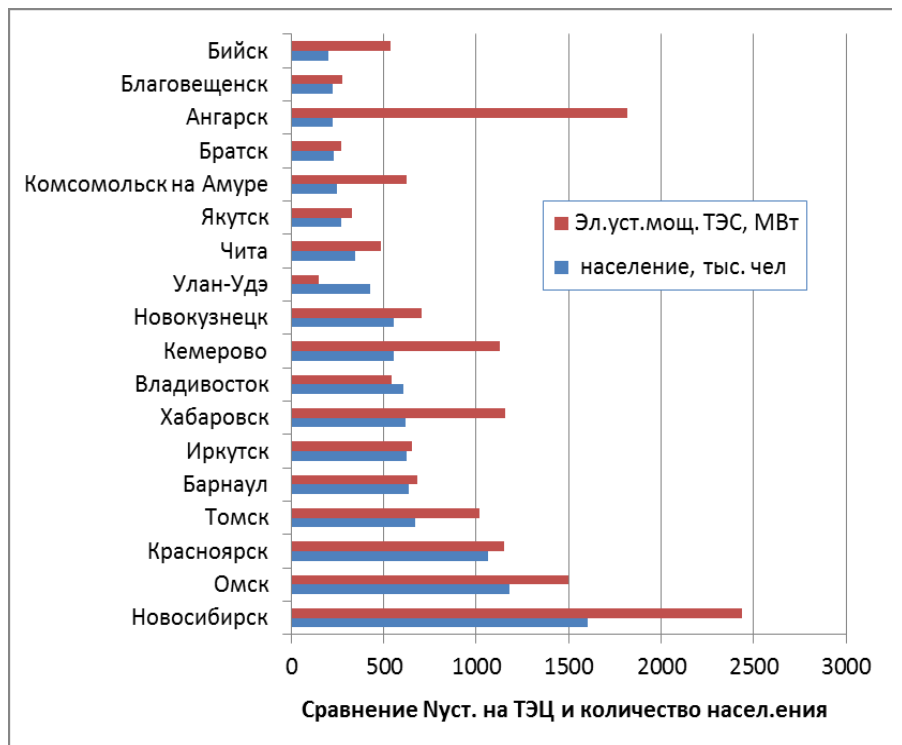

Рис. 3. Установленная электрическая мощность ТЭЦ по городам Сибири, Забайкалья и Дальнего Востока с численностью населения свыше 100 тыс. человек 


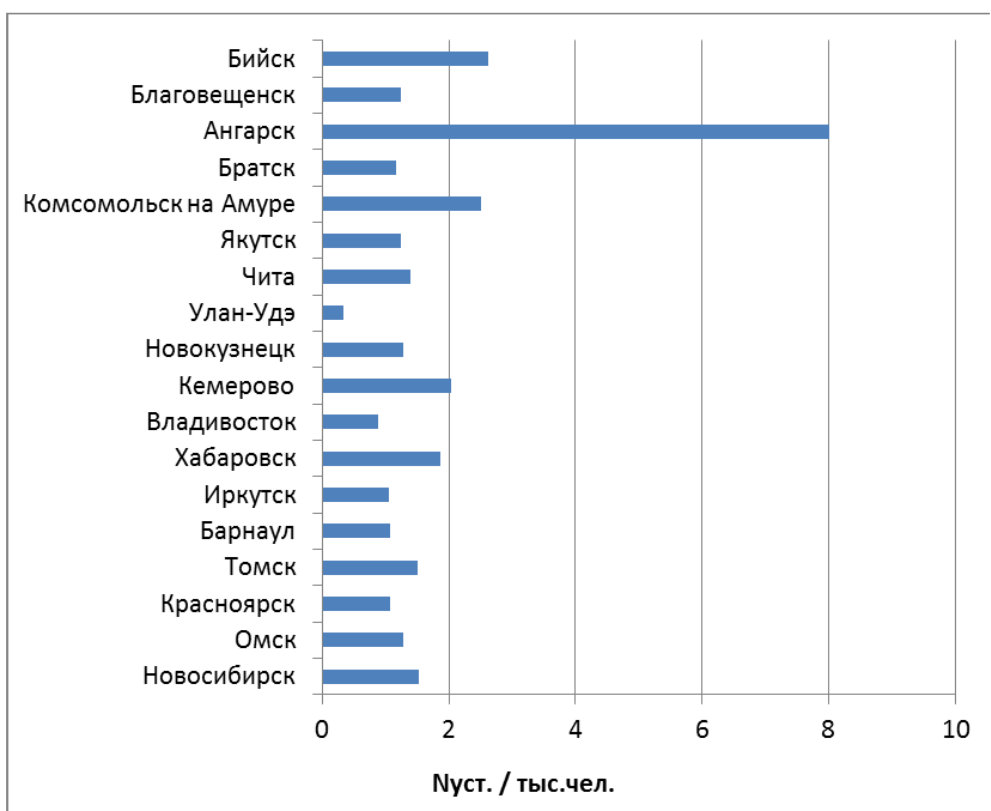

Рис. 4. Удельные значения обеспеченности электрической мощностью ТЭЦ на 1 тысячу человек

Удельные значения обеспеченности являются удобным способом сравнения энергетики городов (рис. 4). Для всех городов, расположенных в Сибири и на Дальнем Востоке, с численностью населения более 100 тысяч человек удельные значения обеспеченности электрической энергией ТЭЦ превышают значение $1 \mathrm{MB}$ т на тысячу человек, кроме г. Улан-Удэ со значением около 0,35 МВт на тысячу человек. В Советском Союзе планировалось строительство Улан-Удэнской ТЭЦ-2 с проектной электрической мощностью на полное развитие 720 МВт, тепловой мощностью 1840 Гкал/час. Электрическая мощность первой очереди строительства составляла 360 МВт, тепловая - 930,2 Гкал/час. Строительство Улан-Удэнской ТЭЦ-2 было начато в 1983 г., а к настоящему времени введена только часть объектов первой очереди. Установленная тепловая мощность пиковой котельной ТЭЦ-2 составляет 380 Гкал/час. От нее осуществляется централизованное теплоснабжение потребителей жилищно-коммунального сектора, а также предприятий и организаций промышленно-складской зоны Октябрьского района. Развал Советского Союза не позволил завершить работы по строительству Улан-Удэнской ТЭЦ-2. Вопрос обеспечения надежности энергоснабжения города остался нерешенным.

Неоднократные обращения правительства Республики Бурятия в Минэнерго РФ о завершении строительства ТЭЦ-2 не получили поддержки со ссылкой на отсутствие в регионе потребности в дополнительной выработке электроэнергии, несмотря на то, что Байкальский регион (Иркутская область, Республика Бурятия, Забайкальский край) уже в течение 5 лет является дефицитным и получает ежегодно более 5 млрд кВт.ч из Красноярского края. Этот дефицит в соответствии с утвержденными схемами и программами развития электроэнергетики этих регионов будет увеличиваться в дальнейшем. В 2012 г. в соответствии с 
протоколом Минэнерго РФ № АШ-185 от 28.04.2012г. было принято решение о необходимости строительства ТЭЦ-2, но через некоторое время за подписью заместителя председателя правительства РФ А. Дворковича пришел отказ в выделении средств на начало строительства.

Совет по вопросам развития Дальнего Востока и Байкальского региона при Совете Федерации Федерального Собрания Российской Федерации решением №4 от 20.12.2018 г. рекомендовал правительству Российской Федерации разработать постановление правительства Российской Федерации, предусматривающее выделение денежных средств для завершения строительства первой очереди Улан-Удэнской ТЭЦ-2, а также внесения изменений в правила оптового рынка электроэнергии и мощности, учитывающих возможность компенсации понесенных капитальных затрат через плату за мощность и Министерству энергетики Российской Федерации рассмотреть возможность включения в Генеральную схему размещения объектов электроэнергетики до 2035 г., утвержденную распоряжением правительства Российской Федерации от 9 июня 2017 г. №1209-p, а также в схему и в программу развития Единой энергетической системы России на 2018-2024 гг., утвержденные приказом Министерства энергетики Российской Федерации от 28 февраля 2018 г. № 121, завершение строительства УланУдэнской ТЭЦ-2 с двумя энергоблоками по 115 МВт.

Однако Минэнерго РФ письмом от 6 декабря 2018 г. практически отказало в решении вопроса строительства ТЭЦ-2 в г. Улан- Удэ. Основные аргументы: профицит электроэнергии в Бурятской энергосистеме, фактическое потребление тепла полностью удовлетворяется существующими источниками (очень спорное утверждение, так как при температурах -20 градусов система теплофикации города не может обеспечить проектных параметров теплоносителя у потребителя, да и расчетная температура -36 градусов держалась не более одной недели и то ночью, проходили за счет аккумулирующей способности зданий). Кроме того, Минэнерго считает, что теплоснабжением города должен заниматься Минстрой в связи с численностью населения менее 500 тыс. человек. В письме совершенно не рассматриваются вышеприведенные в данной статье обоснования необходимости завершения строительства ТЭЦ-2. Отказ от возможности выработки электроэнергии на существующем теплопотреблении не дает возможности ТГК-14 привлечь инвесторов. Дополнительное увеличение выработки тепла на угольных котельных невозможно из-за ухудшения экологической обстановки в городе и дальнейшего увеличения стоимости тепла.

Протокол Минэнерго от 07.02.2019 «О развитии теплоэнергоснабжения Республики Бурятия с учетом необходимости снижения негативных последствий для окружающей среды» (пункт 12 протокола совещания у заместителя председателя правительства Российской Федерации - полномочного представителя президента Российской Федерации в Дальневосточном федеральном округе Ю. П. Трутнева от 26 февраля 2018г. № ЮТ-П16-52пр) показывает, что совещание проведено с целью подтвердить позицию Минэнерго, несмотря на возможность выработки значительного количества электроэнергии с использованием когенерации и значительного улучшения технико-экономических показателей работы энергооборудования города, снижения стоимости тепла и электроэнергии для потребителей, использования значительных капвложений, освоенных на 
ТЭЦ-2. История сооружения Улан-Удэнской ТЭЦ-2 и теплофикации города еще раз наглядно подтверждает, что вопросы теплоэнергоснабжения страны и безопасности требуют пересмотра и решения многих проблем в этой отрасли энергетики $[2 ; 3]$.

При объективном подходе к вопросу о завершении строительства ТЭЦ-2 в г. Улан-Удэ необходимо отметить, что это один из самых конкурентных проектов модернизации и строительства тепловых электростанций, дающий возможность опережающего развития столицы Бурятии и значительного улучшения экологической обстановки [1]. Проект завершения строительства Улан-Удэнской ТЭЦ-2 должен быть включен в Национальную программу развития Дальнего Востока до 2025 г. и на перспективу до 2035 г.

\section{Литература}

1. Борисов Г. О. Проблемы и перспективы развития энергетики Бурятии // ЭКО. 2018. № 10. C. 49-64.

2. Некрасов А. С. Анализ и прогнозы развития отраслей топливно-энергетического комплекса / под ред. В. В. Ивантера. Москва, 2013. С. 383-436.

3. Энергетическая безопасность России: проблемы и пути решения / под ред. Н. И. Воропая и М. Б. Чельцова. Новосибирск: Изд-во СО РАН, 2011. С. 22-30.

\section{ON THE EFFICIENCY OF CONSTRUCTING THERMAL POWER PLANT-2 IN ULAN-UDE}

Gennady O. Borisov

Cand. Sci. (Econ.), Senior Researcher

E-mail: borisovgo@bk.ru

Roman A. Zdarov

Junior Researcher

E-mail: zdarovroman@mail.ru

Buryat Scientific Center SB RAS

8 Sakhyanovoy St., Ulan-Ude 670047, Russia

The article analyzes the state of heat and power supply in Ulan-Ude. We have calculated production balance and consumption of thermal energy, actual and long-term balance plan of burning capacity and heat-flux density in TPP- 1 and TPP-2; presented the data on the actual cost of production and transmission of thermal energy in Ulan-Ude for 2017. The article presents the calculations of economic losses and identifies the reasons for the increased rates to consumers caused by the lag in construction of U-U TPP-2. We have considered the environmental state of Ulan-Ude by the level of air pollution. It has been revealed that for ten years the city has been included in the list of settlements with air alert level. Heat-only boiler stations, TTP-1, TTP-2 and furnace devices of private house buildings are the main sources of pollution. It is shown that the commissioning of U-U TTP-2 will significantly reduce pollution. A decision of the Russian Federation Government and inclusion of the project in the National Program of the Far East Development until 2025 and for the long term until 2035 are the measures necessary to complete the construction of Ulan-Ude TPP-2.

Keywords: Ulan-Ude; TTP-2; heat-only boiler station; benzopyrene; heat and power supply; public utilities; electrical energy industry. 